Research.

\title{
Analysis of consumer behavior in buying instant noodles (case studies in the Bogor City Area)
}

\author{
Mohammad Wartaka ${ }^{1)^{*}}$ Sumardjono Sumardjono ${ }^{2)}$ \\ Department of Management, Indonesian Binaniaga University, Bogor, Indonesia \\ 1'm.wartaka@gmail.com; ${ }^{2}$ sdjonref18@gmail.com \\ ${ }^{*}$ Corresponding author
}

Received: August 31, 2020; Accepted: November 17, 2020; Published: December 31, 2020

To cite this article: Wartaka, M \& Sumardjono,S. (2020). Analysis of consumer behavior in buying instant noodles (case studies in the Bogor City Area). The Management Journal Of Binaniaga, 5 (2),115-128. doi: $\underline{10.33062 / \mathrm{mjb} . v 5 i 2.384}$

\begin{abstract}
This research aims to find out the main attributes consumers consider in instant noodle purchases, and to know their attitudes and behaviors. The data source in this study was obtained from 167 respondents in Bogor City Area.Statistical analysis used in this study includes analysis of multi-attribute models of fishbein, subjective norms and Theory of reasoned action. The result of fishbein analysis is as follows four most important evaluation attribute is the number of flavor variations of 1.56, then ease of obtaining products, product halalness and quick/practical in serving with scores of 1.53, 1.42 and 1.35 respectively. The smallest evaluation value is given to the gift-giving attribute in the sale of 0.59 packs. This illustrates that respondents consider promotional attributes in the form of gifts less important than other attributes. However, the score is still in an important category. From the behavioral model it appears that of the four brands analyzed having a value of $B \sim B I$ positive (greater than zero) this means the consumer behavior for the above brands is good or positive. Indomie has the largest value of 30.58 compared to other brands describing the attitude of consumers inclined to make purchases against larger Indomie.
\end{abstract}

Keywords: Consumer Behavior, Fishbein Analysis, Instant Noodles, Subjective Norm Analysis, Theory of Reasoned Action

\section{INTRODUCTION}

The Covid-19 pandemic forced many people to stay home. This has an impact on changes in household spending. During the pandemic, grocery spending increased by $51 \%$. Global trends also show cooking and eating at home to be a new lifestyle. Moreover, the gathering of families at home also increases food shopping, whether raw or ready meals.

According to the "Big Data Review of the Impact of Covid-19 2020" compiled by the Central Bureau of Statistics (BPS), online sales during this pandemic increased sharply compared to sales in January 2020.In detail, in March 2020 the highest sales were in Food and Beverage, which increased by $570 \%$ compared to January 2020 , while in April 2020, sales of Food and Beverage products jumped sharply to $1070 \%$ of sales in January 2020.

This is in line with the demand for instant noodles had increased as people's activity decreases amid the coronavirus (Covid-19) pandemic. People; especially in urban areas; who need fast and easy food presentation and practically have made instant noodles as complementary food or even substitution for rice as a staple food of Indonesian society.

Mohammad Wartaka and Sumardjono. Analysis of Consumer Behavior in Buying Instant Noodles (Case Studies In The Bogor City Area) 
The composition of instant noodles consists of: wheat which is a complex carbohydrate, fat, salt (potassium carbonate), flavor booster/MSG (monosodium glutamate), dye (tartarzine), and vegetable oil. To add to the benefits of this favorite food, there are manufacturers who add eggs and various vegetables to instant noodles. The added protein and vitamin content no longer makes instant noodles a nutrient-poor food.

The high level of instant noodle consumption by the world community makes Indonesia a huge and potential market for the food industry, including instant noodle manufacturers. The World Instant Noodles Association (WINA) presents the ten largest countries out of a total of 52 countries that consume 106.42 billion instant noodles in 2019.

Table 1 Total Instant Noodle Consumption 2015-2019 (million servings)

\begin{tabular}{rlrrrrr}
\hline No & Country & $\mathbf{2 0 1 5}$ & $\mathbf{2 0 1 6}$ & $\mathbf{2 0 1 7}$ & $\mathbf{2 0 1 8}$ & \multicolumn{1}{c}{$\mathbf{2 0 1 9}$} \\
\hline 1 & China/Hong Kong & 40,430 & 38,520 & 38,960 & 40,250 & 41,450 \\
\hline 2 & Indonesia & 13,200 & 13,010 & 12,620 & 12,540 & 12,520 \\
\hline 3 & India & 3,260 & 4,270 & 5,420 & 6,060 & 6,730 \\
\hline 4 & Japan & 5,540 & 5,660 & 5,660 & 5,780 & 5,630 \\
\hline 5 & Viet Nam & 4,800 & 4,920 & 5,060 & 5,200 & 5,430 \\
\hline 6 & USA & 4,080 & 4,120 & 4,130 & 4,520 & 4,630 \\
\hline 7 & Republic of Korea & 3,650 & 3,830 & 3,740 & 3,820 & 3,900 \\
\hline 8 & Philippines & 3,480 & 3,400 & 3,750 & 3,980 & 3,850 \\
\hline 9 & Thailand & 3,070 & 3,360 & 3,390 & 3,460 & 3,570 \\
\hline 10 & Brazil & 2,370 & 2,370 & 2,250 & 2,390 & 2,450 \\
\hline
\end{tabular}

Source: Global Demand for Instant Noodle, 2020, Word Instant Noodles Association (WINA)

Based on data updated in May 2020, Indonesia itself is in the category of the two largest. When linked to the estimated Population Survey between the Census (SUPAS) BPS in 2015, where the projected population of Indonesia in 2020 reached 269.6 million people, then with a consumption rate of 12.52 billion packs per year, on average every Indonesian consumes 46 packs of instant noodles per year.

Table 2 Instant Noodle Sales 2008-2015

\begin{tabular}{rlcccccccc}
\hline No & Brand & $\mathbf{2 0 0 8}$ & $\mathbf{2 0 0 9}$ & $\mathbf{2 0 1 0}$ & $\mathbf{2 0 1 1}$ & $\mathbf{2 0 1 2}$ & $\mathbf{2 0 1 3}$ & $\mathbf{2 0 1 4}$ & $\mathbf{2 0 1 5}$ \\
\hline 1 & Indomie & $81.4 \%$ & $79.1 \%$ & $76.5 \%$ & $73.2 \%$ & $69.0 \%$ & $65.2 \%$ & $65.3 \%$ & $60.0 \%$ \\
\hline 2 & Mie Sedap & $12.0 \%$ & $15.0 \%$ & $17.0 \%$ & $19.3 \%$ & $23.0 \%$ & $26.8 \%$ & $26.8 \%$ & $20.0 \%$ \\
\hline 3 & Others & $3.2 \%$ & $2.9 \%$ & $2.8 \%$ & $3.0 \%$ & $3.5 \%$ & $4.0 \%$ & $4.1 \%$ & $20.0 \%$ \\
\hline
\end{tabular}

Source: Indonesian Consumer Profile 2015, MARS RESEARCH INDONESIA

One of the instant noodle products that has a strong brand image in the minds of consumers is instant noodle products with Indomie brand produced oeh one of the largest food products in Indonesia namely PT.Indofood Sukses Makmur Tbk.Extensive international sales make Indomie a halal brand of instant noodles in Indonesia (Primus, 2016). However, since 2003 Indofood's dominance in the instant noodle market began to decline with the presence of Mie Sedap owned by PT Sayap Mas Utama, a business venture of Wings Group.The decrease in the share of Indofood in instant noodles was seen in 2008 the share of its market $81.4 \%$, then decreased to $73.2 \%$ in 2011 , and in 2015 about $60.7 \%$.

Today's strict instant noodle competition conditions encourage consumers to identify in decision-making when determining the choice of a brand that they think meets the criteria of an instant noodle product they want. The identification process will make 
the brand a differentiating tool and can also be the main criterion in the consumer purchasing decision making process

For consumers, the market provides a large selection of goods and services, and consumers are free to choose the products and brands that they will buy so that the purchasing decision is entirely on the consumer.

\section{PROBLEM FORMULATION}

Based on the background above, the formulation of the issues that will be discussed in this research includes:

1. What factors influence decisions in the purchase of instant noodle products?

2. What is the relationship between consumer attitude and instant noodle product purchase?

3. What is the relationship between consumer behavior and instant noodle product purchase?

\section{LITERATURE REVIEW}

\section{Consumer Behavior}

Engel, et al.(1999), states that consumer behavior is an act directly involved in obtaining, consuming, and consuming products and services, including decision processes that precede and follow these actions. Furthermore Sutisna (2001), added that understanding consumer behavior is a very important action, because the marketing program that will be run by the company must rest on the needs and desires of consumers. Sumarwan (2011) states that consumer behavior is all activities, actions, and psychological processes that drive such actions in the time before purchasing, when buying, using, consuming products and services after doing the above or all evaluating activities.

The American Marketing Association defines consumer behavior as a dynamic interaction between influence and cognition, behavior and events around us, where humans conduct exchange aspects of their lives. There are three important ideas in understanding the definition: (1) consumer behavior is dynamic, (2) it involves the interaction between influence and cognition, behavior, and events around, and (3) it involves exchange (Peter and Olson.2010).

Engel further, et al.(1994) states that in deciding to consume an item, the consumer decision process is influenced by the following three main factors:

a. Environmental influences, including culture, social class, personal influence, attitudes and situations.

b. Individual differences consist of consumer resources, motivation and engagement, knowledge, attitudes, personalities, lifestyles and consumer demographics.

c. Psychological processes include information processing received through impressed delivery, learning process (development and experience) and changes in attitude or behavior (influenced by information process and learning process).

In consumer decision making, the marketing mix also influences the decisionmaking process and each purchase becomes an experience that also influences the consumer decision process (Schiffman and Kanuk, 2015).

Evans and Berman (1995) stated that knowing the consumer behavior and desired needs of a product would have a positive impact on the marketing success of a company's products. In order to obtain consumer satisfaction, the company must be able to know the attributes of the products and services desired by consumers, such as physical and non-physical attributes (model, shape, quality, price, color, taste, durability, security and warranty of the products used). 


\section{Consumer Preferences}

According to Tjiptono (2002), consumer preference is closely related to consumer assessment of satisfaction or dissatisfaction with products or services even in certain companies, in evaluating the level of satisfaction with the product, there are several indicators that are often used among others:

a. Performance characteristics of the core products purchased, such as products consumed are practical to carry.

b. Additional features include secondary or complementary characteristics, such as smooth textures, attractive packaging design and product shape and low price.

c. Reliability, i.e. it is less likely that the product used will suffer damage, such as the product consumed is not often damaged or cannot be consumed again

d. Conformity to specifications i.e. what the design features and shape of the product is maintained, standards in accordance with existing provisions, for example food products must meet health standards set by the Ministry of Health or have halal certificate.

e. Durability, related to how long the product can continue to be used, such as product expiration.

f. Service abilities are including speed, competence, comfort and convenience.

g. Aesthetics are factors that become the product's attraction to the five senses such as the physical shape of colors and models.

h. Perceived quality is the image and reputation of the product, such as the brand.

To measure consumer preference for products and services according to Engel et al.(1994) in Eduardsah and Wartaka (2018) a measurement model is required that can analyze the relationship between the knowledge of the product owned by the consumer and the attitude of the product according to the characteristics or attributes of the product. Based on this analysis can be done an effort to foresee marketing based on consumer behavior. Thus knowledge about consumption can be used as a critical determinant in business decision making.

Engel et al. (1994) in Eduardsah and Wartaka (2018) stated that attitudes are a thorough evaluation that can range from extreme positive to extreme negative. The attitude is formed as a result of previous consumer's experience. Therefore the attitude is more static. In order to anticipate the change in consumer attitudes, the company needs to track consumer attitudes all the time. In addition, these efforts can be utilized to assess the effectiveness of marketing activities, evaluate marketing actions before they are implemented in the market and select the target market.

\section{Fishbein's Attitude and Behavior Model}

According to Engel et al.(1994) in Eduardsah and Wartaka (2018) The multiattribute attitude model describes a valuable design to examine the relationship between the knowledge that consumers have and attitudes towards products related to product traits or attributes. Fishbein's model suggests that attitudes towards consumers towards a particular object are based on a device of trust summarized regarding the attributes of the object in question that is weighted by the evaluation of those attributes. This model is called multi-attribute because the consumer's evaluation of an object is based on its evaluation of many attributes owned by that object.

Fishbein's Multi Attribute Attitude model consists of three models: the attitudetoward-object model, the attitude-toward behavior model and the theory of reasonedaction model. The multi-attribute model emphasizes the salience of attributes, which means the level of importance is given by the consumer to an attribute. The model draws that a consumer's attitude towards a product or brand is determined by two things, 
namely trust in the attributes of the product or brand and the evaluation of the importance of the attributes of the product Sumarwan (2013).

In this research, the theory of reasoned action (TRA) model will be used. The Theory of Reasoned Action model, assumes that consumers are consciously considering the alternative consequences of the behavior being considered, and chooses one that can have the most expected consequences. The result of this TRA process is one desire to engage in selected behavior (Wartaka, 2016).Desire to behave is a real good behavior prediction tool. The frame of thought in this theory can be seen in Figure 1.

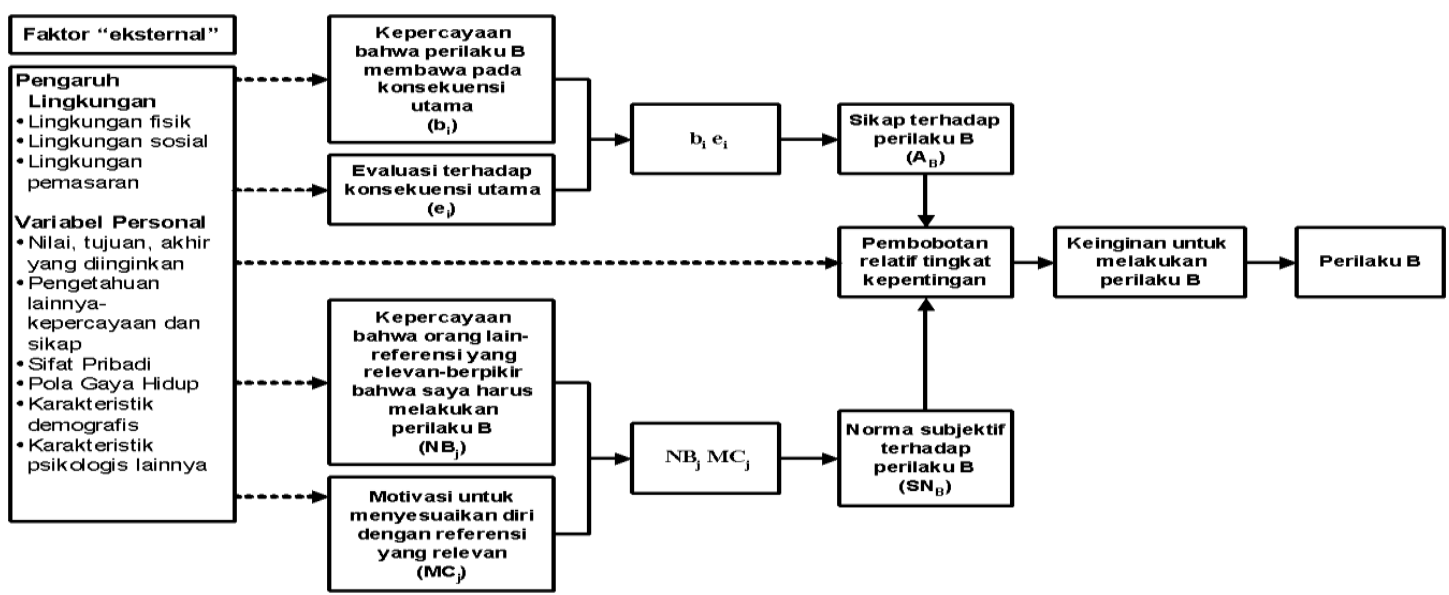

Figure 1. Theory of Reasoned Action Adapted from Martin Fishbein's "An overview of the attitude construct" in a look back, a look ahead, (ed) G.B Hafer (Chicago: American Marketing Association, 1980) in Peter and Olson (2010)

In Figure 1 it appears that the Theory of Reasoned Action model consists of two components namely the Attitude component and the Subjective Norm component. Attitude model is reflecting individual perceptions of consumers. This model is directly related to research objects and direct attributes that have an important role in behavioral measurement. The Subjective Norm component is reflecting consumers' perceptions of what they think others want them to do.

\section{Previous Research Studies}

Eduardsah and Wartaka, M (2018) conducted the same research on the analysis of instant noodle consumer behavior in South Jakarta region, a study conducted on 200 respondents using Fishbein and TRA analysis concluded that the four most important evaluation attribute is the number of flavor variations of 2.57 , then practicality in serving, product halal-ness and ease of obtaining products with a score of 2.54 each 2.48 and 2.46. The smallest evaluation value is given on the packaging attribute of 1.58 .While from the behavioral model it appears that from the four brands (Indomie, Mie Sedap, Alhami , Gagamie) analyzed has a value of B BI positive (greater than zero) this means the consumer behavior for the above brand is good or positive.

While the research conducted by Laras, G.M.D.and Firmansyah, E (2018) on 100 respondents in Bandung concluded that aspects of Indomie purchasing decisions are good enough with an average score of 3.91 which means that cultural factors, social factors, personal factors, and psychological factors influence respondents in their decision-making to choose Indomie products.

Maruhum (2001) has researched the analysis of consumer behavior towards the attributes of instant noodle products in Bogor. The study of 135 respondents concluded that the attributes considered by consumers in consuming noodles in a row according to their weight were: variety of flavors (1.44), additional nutrition (1.43), price (1.33), ease of serving (1.29), length of cooking (1.21), weight (1.20) and packaging (0.68).While the brands of noodles analyzed are: Indomie, Supermie, Salamie, Sarimie, Mie ABC and Gaga Mie.

Mohammad Wartaka and Sumardjono. Analysis of Consumer Behavior in Buying Instant Noodles (Case Studies In The Bogor City Area) 


\section{RESEARCH METHODOLOGY}

\section{Populations and Samples}

The method used is a method of consumer survey conducted in Bogor City. Considering that it is still in the Covid-19 pandemic and the enactment of PSBB in Bogor City, sampling is done with the spread of Google Form. In this study the respondents selected were final consumers who consumed instant noodles.

At the selected location of the interview to the respondent is done in convenience sampling, namely the researcher selects the person who is easy to sample, and the method of sampling judgement, with this method the researcher uses his own assessment to select members of the population who can provide accurate information with the criteria that have been determined by the researcher.Respodent surveyed 225 people in Bogor City Area.This technique was chosen because there is no customer or consumer data. Of the above, the processable sample is 167 respondents, while the rest cannot be used because of incomplete.

\section{Data Analysis}

The analysis used in this study is using Fishbein's Attitude and Behavior Analysis Model, this analysis will measure consumer confidence in an instant noodle atribute, and then evaluate for each brand analyzed. The results will be compared to subjective norms for measuring consumer behavior towards instant noodle purchases.

This model emphasizes the salience of attributes, which is the level of importance that consumers give to an attribute. The model illustrates that a consumer's attitude towards a product or product brand is determined by two things: (1)trust in the attributes of the product or brand (bi component), and the evaluation of the importance of the attributes of the product (component $e l$ ), which are illustrated in the following formula:

$$
A_{0}=\sum_{i=1}^{n} b_{i} e_{i} \quad \begin{aligned}
& \text { where: } \\
& \mathrm{A}_{0}=\text { Attitude towards objects } \\
& \mathrm{b}_{\mathrm{i}}=\text { The strength of the belief that the object has the } \mathrm{i} \text { attribute } \\
& \mathrm{e}_{\mathrm{i}}=\text { Evaluation of } \mathrm{i} \text { attribute } \\
& \mathrm{n}=\text { The number of attributes the object has }
\end{aligned}
$$

The ei component measures the evaluation of the importance of the attributes that an object has, the consumer has not noticed the brand of a product when evaluating the importance level of that attribute.Meanwhile, the bi component measures the level of consumer confidence in the attributes owned by each brand.Consumers should pay attention to the brand of a product when evaluating the attributes owned by each brand.

Fishbein's model presents three main concepts:

a. Attribute (Salient Belief), attribute is characteristic of object attitude $\left(\mathbf{A}_{\mathbf{0}}\right)$.

b. Salient belief is a consumer belief that products have various attributes often called atribute-object beliefs.In the study will be identified various attributes that consumers consider when evaluating an attitude object $\left(\mathbf{A}_{0}\right)$. For example, the car will have model attributes, brand, number of cc, transmission type.

c. Belief, trust is the strength of trust that a product has a variety of certain attributes. Consumers will express confidence in the various attributes that a brand and product it evaluates, this step is described by bi.These beliefs are often called object-atribute linkages, i.e. consumer confidence about the possible relationship between an object and its relevant attributes. 
This model briefly states that a consumer's attitude towards an object is determined by his or her attitude towards the various attributes that the object has. The ei component describes how important an attribute is to a consumer before the consumer notices the brand of a product when evaluating the importance of that attribute. The attributes used for the ei component must be the same as the attributes used to calculate bi components, usually measured on a 5-digit scale from the realized possibilities lined from very important to not very important.

The bi component describes consumer confidence in the attributes of a brand. Consumers should pay attention to the brand of a product when evaluating the attributes of a brand. Trust is usually measured characteristically on a 5-digit trust scale $(2,1,0,-1$, $-2)$.

The average response is then calculated for each bi and ei size. In interpreting the results keep in mind that the bi and ei scales range from a maximum score of 2 to a minimum score of -2 . To estimate the attitude $\left(A_{\circ}\right)$ to the product by using the $\sum$ biei each trust score (bi) should be multiplied by the corresponding evaluation score (ei). Then all multiplication results must be summed up to know the consumer's attitude towards the product. The maximum attitude value ( $A_{\circ}$ max) is obtained by combining the ideal trust score which is a maximum of 2 with an evaluation of the importance of each attribute. The value obtained is reduced by consumer attitude $\left(A_{\circ}\right)$. The difference between $A_{\circ}$ max and $A_{\circ}$ is calculated to determine the contribution of the resulting value if there will be changes to the product attributes.

\section{Subjective Norm Model}

Subjective norm components are external individuals that affect consumers making product purchases. This component can be calculated by multiplying the value of an individual's normative belief in an attribute and the motivation of agreeing to an attribute. Normative power means a person's strong normative belief in the atribute offered to influence his or her behavior towards the object. While the motivation of agreeing is the motivation of a person to agree with the attribute offered as a factor that affects his behavior (Umar, 2003).

The Subjective Norm model is mathematically illustrated with the following formulas:

$$
S N=\sum_{i=1}^{n} N B_{i} M C_{\tilde{i}}
$$

where:

$$
\begin{aligned}
& \mathrm{SN}=\text { Subjective Norms } \\
& \mathrm{NBi}_{\mathrm{i}}=\text { Normative Beliefs } \\
& \mathrm{MCi}_{\mathrm{i}}=\text { Consumer's Motivation } \\
& \mathrm{n}=\text { Number of relevant referrals }
\end{aligned}
$$

$$
\begin{aligned}
& \text { Formally Theory of Reasoned Action can be presented as follows: } \\
& B \sim B I=A_{\text {act }}\left(W_{1}\right)+S N\left(W_{2}\right) \\
& \qquad \begin{array}{l}
\text { where: } \\
\mathrm{B}=\text { Special Behavior } \\
\mathrm{Bl}=\text { Consumer desire is involved in this behavior } \\
A_{\text {act }}=\text { Consumer's Attitude } \\
\mathrm{SN}=\text { Subjective Norms } \\
\mathrm{W}_{1} \text { dan } \mathrm{W}_{2}=\text { Relative Weight }
\end{array}
\end{aligned}
$$




\section{Research Attributes}

Based on previous research and observation results, research attributes for trust variables (bi) and evaluation (ei) consist of:

1. Wide variety of flavors,

2. Contains many vitamins / nutritional content,

3. Cheap / economical price,

4. Quick and practical in presentation,

5. Attractive packaging,

6. Product halal-ness,

7. More portions, Ease in obtaining, and

8. Gifting in the promotion of purchase

While the research attributes for normative belief variables (NBi) and motivation (MCi) consist of:
1. Family,
2. Friends,
3. Promotional officers/props
4. In addition to family, friends, and promotional officers/props

\section{RESULTS AND DISCUSSION}

\section{Fishbein's Attitudes Analysis}

In Table $3 \& 4$ it appears that the most important evaluation attribute is (1) the number of flavor variations of 1.56 , then (2) ease of obtaining, (3) product halalness and (4) quick/practical in serving with scores of $1.53,1.42$ and 1.35 respectively.The smallest evaluation value is given to the gift-giving attribute in the purchase of 0.59 . This illustrates that respondents considered the instant noodle sales promotion attribute to be less important than other attributes. However, the score is still in an important category (see scale range).

For Indomie brand respondents gave the highest confidence score on the many flavor variations of 4.61, and the ease of obtaining products of 4.51.This is indeed one of the advantages of Indomie compared to its competitors, because it provides a lot of variety of flavors, ranging from traditional flavors and foreign flavors in noodle products, besides always paying attention to the distribution of products to the corners of the country ranging from modern retail to small stalls in the countryside.

For the lowest value given by respondents on the attribute of gift-giving sales and economical prices of 3.60 and 3.72. As a market leader Indofood rarely gives sales promotion prizes like its competitors, sedankan price more than its competitors. The average attitude score is 45.53 which means the respondent's attitude towards Indomie is good.

Table 3 Respondents' attitude towards instant noodle attributes in Bogor City Area

\begin{tabular}{|c|c|c|c|c|c|c|c|c|c|}
\hline \multirow{2}{*}{\multicolumn{3}{|c|}{ Attributes }} & \multirow{2}{*}{$\begin{array}{c}\text { Evaluation } \\
e i\end{array}$} & \multicolumn{3}{|c|}{ Trust (bi) } & \multicolumn{3}{|c|}{ Total (ei $\times$ bi) } \\
\hline & & & & IND & MS & POP & IND & MS & POP \\
\hline 1 & Variations of Flavors & 1 & 1.56 & 4.61 & 4.04 & 4.03 & 7.18 & 6.29 & 6.27 \\
\hline 2 & Contains Vit. / Nutritious & 1 & 1.30 & 4.25 & 3.98 & 3.89 & 5.52 & 5.17 & 5.05 \\
\hline 3 & Economical Price & 1 & 0.88 & 3.72 & 3.62 & 3.70 & 3.27 & 3.18 & 3.26 \\
\hline 4 & Fast / Practical in Serving & 1 & 1.35 & 4.34 & 4.11 & 4.38 & 5.88 & 5.56 & 5.92 \\
\hline 5 & Attractive Packaging & 1 & 1.15 & 4.10 & 3.85 & 4.01 & 4.71 & 4.43 & 4.61 \\
\hline 6 & Product Halal-ness & 1 & 1.42 & 4.32 & 4.12 & 4.09 & 6.13 & 5.85 & 5.80 \\
\hline 7 & Large Portions & 1 & 0.98 & 3.90 & 3.81 & 4.54 & 3.81 & 3.72 & 3.46 \\
\hline 8 & Easy to Get & 1 & 1.53 & 4.51 & 4.11 & 4.12 & 6.92 & 6.31 & 6.32 \\
\hline
\end{tabular}




\begin{tabular}{|c|c|c|c|c|c|c|c|c|c|}
\hline \multirow{2}{*}{\multicolumn{3}{|c|}{ Attributes }} & \multirow{2}{*}{$\begin{array}{c}\text { Evaluation } \\
e i\end{array}$} & \multicolumn{3}{|c|}{ Trust (bi) } & \multicolumn{3}{|c|}{ Total (ei x bi) } \\
\hline & & & & IND & MS & POP & IND & MS & POP \\
\hline \multirow[t]{3}{*}{9} & Gift-Giving in Purchasing & 1 & 0.59 & 3.60 & 3.49 & 3.55 & 2.11 & 2.05 & 2.08 \\
\hline & & & 10.75 & 37.35 & 35.13 & 35.31 & 45.53 & 42.55 & 42.77 \\
\hline & & & & \multicolumn{3}{|c|}{ INTERPRETATION } & Good & Good & Good \\
\hline
\end{tabular}

Second place in the attitude score is Pop Mie, a product that still comes from the same manufacturer as Indomie which brings practical issues in the presentation and targets the segment of young people according to the respondent's assessment with a score of 4.38.This score is higher than the market leader with a score of 4.34 compared to Mie Sedap of 4.11.The overall trust score is slightly above Mie Sedap.Total attitude score for Pop Mie is 42.77 with good category.

Table 4 Ranking of instant noodle attributes in Bogor City Area

\begin{tabular}{llcccc}
\hline & \multirow{2}{*}{ Attributes } & \multicolumn{4}{c}{ Ranking } \\
\cline { 3 - 6 } & & Ei & IND & MS & Pop \\
\hline 1 & Variations of Flavors & 1 & 1 & 4 & 4 \\
\hline 2 & Contains Vit. / Nutritious & 5 & 5 & 5 & 6 \\
\hline 3 & Economical Price & 8 & 8 & 8 & 7 \\
\hline 4 & Fast / Practical in Serving & 4 & 3 & 3 & 1 \\
\hline 5 & Attractive Packaging & 6 & 6 & 6 & 5 \\
\hline 6 & Product Halal-ness & 3 & 4 & 1 & 3 \\
\hline 7 & Large Portions & 7 & 7 & 7 & 9 \\
\hline 8 & Easy to Get & 2 & 2 & 2 & 2 \\
\hline 9 & Gift-Giving in Purchasing & 9 & 9 & 9 & 8 \\
\hline & Source: Primary data, 2020 & & & &
\end{tabular}

The average trust value for Mie Sedap is in the range of $3.49-4.04$, which describes generally respondents agreeing that Mie Sedap has an evaluated attribute $(e i)$.The highest score of 4.04 for the product's halal attribute, medium for the ease of obtaining attribute and the quick/practical score is 4.11.The company's strategy to rival Indofood, by street positioning as a product of the same quality with cheaper prices and heavier portions. The total score of 42.55 makes noodles delicious to rank third after Indomie and Pop Mie with good category.

Table 5 Research Scale Range

\begin{tabular}{|llll}
\hline \multicolumn{2}{|c}{ EVALUATION SCALE } \\
-2.0 & to & -1.20 & Very Unimportant \\
-1.21 & to & -0.40 & Unimportant \\
-0.41 & to & 0.40 & Conventional \\
0.41 & to & 1.20 & Important \\
1.21 & to & 2.0 & Very Important \\
TRUST SCALE & & \\
1.0 & to & 1.80 & Strongly Refuse \\
1.81 & to & 2.60 & Refuse \\
2.61 & to & 3.40 & Normal \\
3.41 & to & 4.20 & Agree \\
4.21 & to & 5.00 & Strongly Agree \\
ATTITUDE SCALE & \\
-90.0 & to & -54.0 & Worst \\
-54.01 & to & -18.0 & Poor \\
-18.01 & to & 18.0 & Fair \\
18.01 & to & 54.0 & Good \\
54.01 & to & 90.0 & Very Good \\
NORMATIVE SCALE & \\
-40.0 & to & -24.0 & Strictly Forbid \\
-24.01 & to & -08.0 & Forbid \\
-08.01 & to & 8.0 & Neutral \\
08.01 & to & 24.0 & Recommend \\
24.01 & to & 40.0 & Highly Recommend
\end{tabular}

Mohammad Wartaka and Sumardjono. Analysis of Consumer Behavior in Buying Instant Noodles (Case Studies In The Bogor City Area) 


\section{Subjective Norm Analysis}

An individual's subjective norm of a particular behavior is influenced by two components, namely the individual's normative belief that a group or person of preference wants that individual to perform or not perform an activity. The second is the individual's motivation to obey such normative beliefs. In this study subjective norms were measured according to the brand of noodles consumed by respondents whose results were seen in Table 6.

From Table 6 it can be concluded that the external factors that affect the purchase of instant noodles are friends and promotional officers with the same SN hamper value of 3.06 and 3.05.This can be done by the company by putting an emphasis on product promotion, either through endorsements through social media or above line for example through TV media.

Table 6 Subjective Norms of Respondents to instant noodle purchases in Bogor City Area

\begin{tabular}{llrrr}
\hline \multirow{2}{*}{ No } & \multirow{2}{*}{ Attributes } & \multicolumn{3}{c}{ Subjective Norm } \\
\cline { 3 - 5 } & & NB & NC & \multicolumn{1}{c}{ SN } \\
\hline 1 & Family & 0.86 & 3.40 & 2.91 \\
\hline 2 & Friends & 0.93 & 3.30 & 3.06 \\
\hline 3 & Promotion Officers & 0.92 & 3.31 & 3.05 \\
\hline \multirow{2}{*}{4} & Others than family, friends and Promotion & 0.74 & 3.23 & 2.40 \\
\hline & Officers & \multicolumn{4}{c}{ Recommend } \\
\hline & TOTAL & $\mathbf{3 . 4 5}$ & $\mathbf{1 3 . 2 3}$ & $\mathbf{1 1 . 4 2}$ \\
\hline & INTEPRETATION & \multicolumn{4}{c}{} \\
\hline & GM & \multicolumn{4}{l}{}
\end{tabular}

\section{Theory of Reasoned Action Analysis}

Analysis of Fishbein's attitude can be seen in the reliability and relationship with subjective norms by using Theory of Reasoned Action, this is to test whether the respondent's attitude is strongly related to his purchasing behavior.

Table 7 Calculation of Internal and External Attitude weights

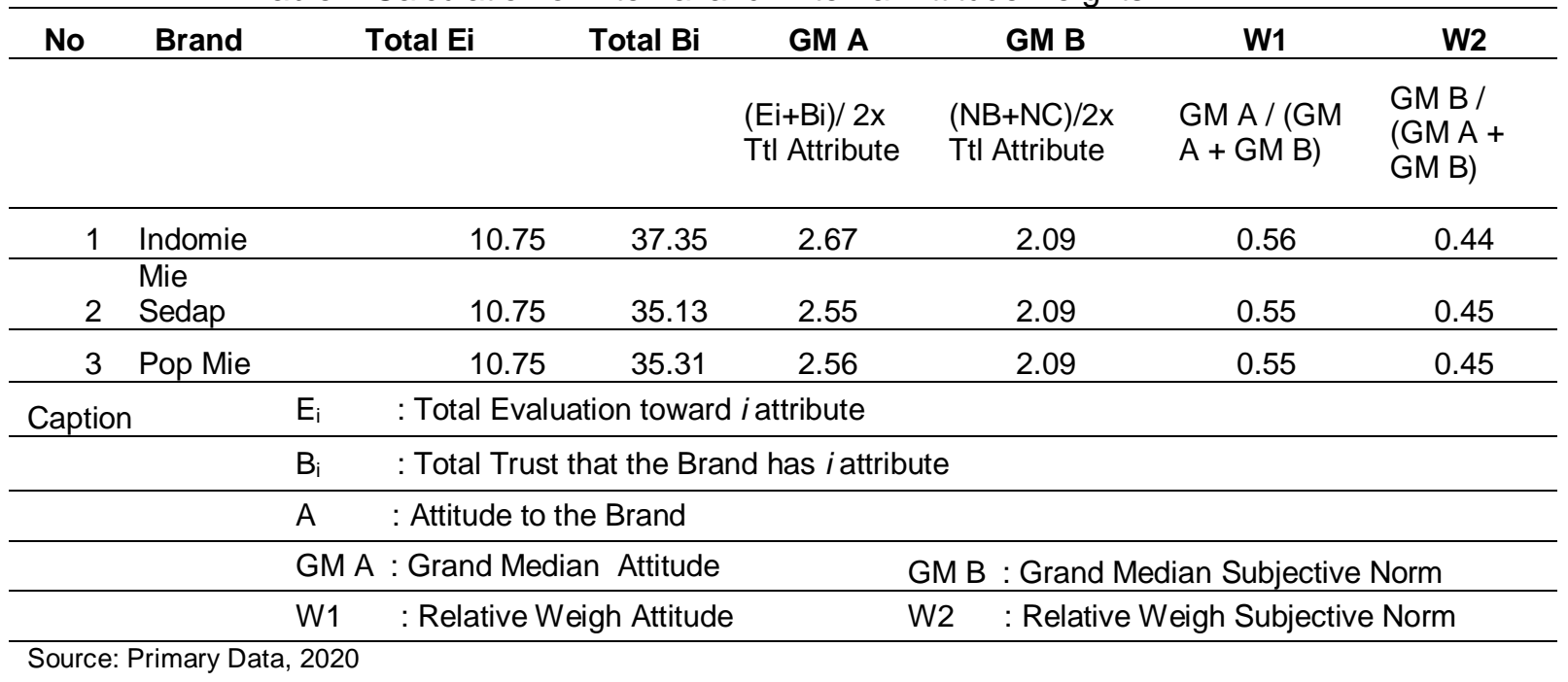

From Table 7 it can be seen that the amount of internal influence (attitude) is greater than external influences (subjective norms).It can also be seen that the weight of internal influence (attitude) of Indomie (0.56) is slightly stronger when compared to the internal influence of respondents on other brands analyzed.

Once the weight value for each brand is obtained, it is then searched for behavioral values against each brand whose results appear in Table 8

Mohammad Wartaka and Sumardjono. Analysis of Consumer Behavior in Buying Instant Noodles (Case Studies In The Bogor City Area) 
.From Table 8 it appears that for all three brands analyzed the value of $\mathrm{B} \sim \mathrm{BI}$ is positive (greater than zero) then the consumer behavior for the above brands is good or positive. Indomie has the largest value of 30.58 compared to other brands describing the attitude of consumers inclined to make purchases against Indomie is larger

Table 8 Calculation of instant noodle respondents' purchasing behavior in Bogor City Area

\begin{tabular}{|c|c|c|c|c|c|c|c|}
\hline No & Brand & & Aact & Sn & W1 & W2 & $B \sim B \mid$ \\
\hline 1 & Indomie & & 45.53 & 11.42 & 0.56 & 0.44 & 30.58 \\
\hline 2 & $\begin{array}{l}\text { Mie } \\
\text { Sedap }\end{array}$ & & 42.55 & 11.42 & 0.55 & 0.45 & 28.54 \\
\hline 3 & Pop Mie & & 42.77 & 11.42 & 0.55 & 0.45 & 28.69 \\
\hline & Caption & B & : A Special & havior & & & \\
\hline & \multicolumn{7}{|c|}{ BI : The Consumer's Desire to Engage in the Behavior } \\
\hline & & \multicolumn{6}{|c|}{ Aact : The Consumer's Attitude to Engage in the Behavior } \\
\hline & & \multicolumn{6}{|c|}{ SN : Subjective Norm } \\
\hline & & \multicolumn{6}{|c|}{ W1 : Relative Weight of Attitude } \\
\hline & & \multicolumn{4}{|c|}{$\begin{array}{l}\text { W2 : Relative Weight of Subjective } \\
\text { Norm }\end{array}$} & & \\
\hline
\end{tabular}

\section{Marketing Strategy Implications}

The instant noodle industry in Indonesia is at an adult stage in the life cycle of products characterized by high levels of competition, so policies or marketing strategies that will have implications will look at the brand's position in the mature industry.

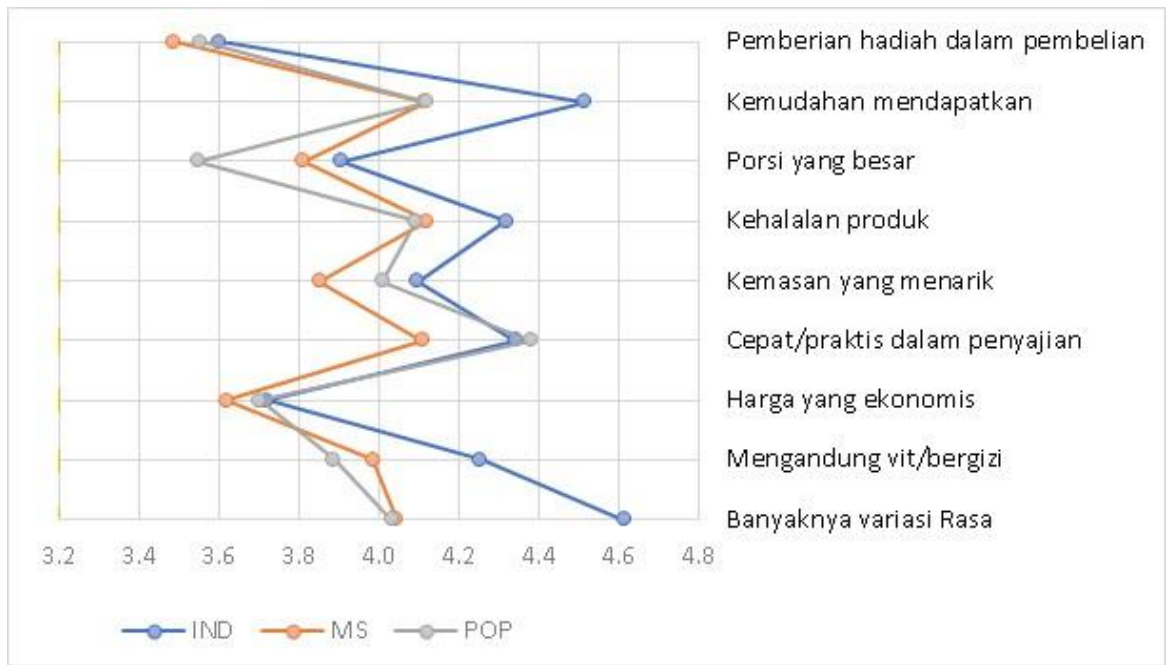

Figure 2 Semantic Differential Analysis on Instant Noodle Products

The map of strength per attribute studied appears in Semantic Differential Analysis in Figure 2 above.

The strategy that will be presented is a strategy at a functional level that includes product strategy, price, promotion, and place.

\section{a. Product Strategy}

For Indomie as the leader of the strategy taken is to master the market share, this can be done by keeping the value of trust for the most important attribute by the respondent (the variety of flavors, the ease to obtain and the halal-

Mohammad Wartaka and Sumardjono. Analysis of Consumer Behavior in Buying Instant Noodles (Case Studies In The Bogor City Area) 
ness of the product) remain high. For other brands as challengers (Mie Sedap) the strategy taken is to position as a product of the same quality with cheaper prices and more portions from the market leader. In addition to having to increase the value of trust that is still weak that is the attribute of gift giving in the purchase either in the form of price discounts or sweepstakes. As the main product coating, Popmie's position is good enough by targeting the younger generation by offering quick/practical attributes in presentation, in addition to the need to improve the nutritional content attributes that respondents consider still weak.

\section{b. Price Strategy}

For Indomie as the leader of the strategy taken is to lead in terms of price changes by applying prices that do not differ much from the challengers. For other brands as challengers (Mie Sedap) the strategy taken is to continue to efficiently cost leadership, among others can be done by designing a lower sales base price (HPP) than the market leader. For Popmie to keep prices from going too far with competitors so that it can compete to maintain a consumer share that is still sensitive to price.

\section{c. Promotion Strategy}

For Indomie as a leader the strategy taken is to maintain and increase the intensity of promotion mainly through above line such as through television advertising and mainstream media.For other brands as challengers (Mie Sedap) the strategy taken is challenging through television media advertising and sales promotions such as gift-giving. For Popmie, promotional strategies by emphasizing on key attributes and attributes that are still weak.

\section{d. Place Strategy}

For Indomie as the leader, the strategy that taken with concentrate and conciliation on the distribution line with already mastered. For other brands as challengers (Mie Sedap) the strategy taken is to expand the existing distribution channels continuously.

\section{CONCLUSIONS AND SUGGESTIONS}

\section{Conclusions}

The results of research on the analysis of consumer attitudes and behavior towards instant noodle products in Bogor City Area are as follows:

1. The order of attributes that influence instant noodle purchasing decisions from the most important is (1) the number of flavor variations (1.56); (2) ease of obtaining (1.53); (3) product halal-ness (1.42); (4) fast/practical in presentation (1.35) ; (5) contains vitamins /nutrients (1.30); (6) attractive packaging (1.15); (7) large portions (0.98); (8) economical price (0.88); and (9) gift-giving in sales (0.59).

2. Consumer attitude in instant noodle purchase analyzed namely Indomie brand, Mie Sedap, Pop Mie is in the category of good. This is seen from attitude values of 45.53 , 42.55 , and 42.77 respectively.

3. Consumer behavior for noodle brands analyzed namely Indomie brand, Mie Sedap, Pop Mie is positive. This can be seen from successive behavior values (B BI) as follows: $30.58,28.54$, and 28.69.

\section{Suggestions}

1. In producing instant noodles noodle manufacturers should place more emphasis on attributes with higher weight such as the many variations of flavors, the ease of 
obtaining instant noodle products compared to other low-weight attributes such as gift-giving in sales.

2. The marketing strategy that can be taken is: as the leader of the product strategy taken is to maintain the value of trust for the most important attribute by the respondent (evaluation) remains high, as the challenger product strategy taken is to look for weaknesses of the value of the leader's trust. Meanwhile, as followers strive to improve the respondent's ability to attribute the evaluated product, i.e. by imitating/matching the leader's product.

\section{REFERENCES}

Badan Pusat Statistik. (2020). Tinjauan Big Data Terhadap Dampak Covid-19. Penerbit BPS. Jakarta

Dubrin, A.J. (2010). Essential of Management (9th Edition). Cengage Learning. USA

Eduardsah \& Wartaka, M. (2018). Model Analysis of Customers' Attitude and Behaviour upon Instant Noodle Products, The Management Journal of BINANIAGA, 3(1), 71 - 82. doi : http://dx.doi.org/10.33062/mjb.v3i1.183

Kotler, P., \& Keller, K. Lane.(2015). Marketing Management. (15th Edition). Pearson Education. USA

Laras, G. M. D., \& Firmansyah, E. (2018). Citra Merek dan Keputusan Pembelian Konsumen: Kasus pada Produk Mie Instan. Jurnal Wawasan Manajemen, 6(2).

MARS Research Indonesia. (2015). Indonesian Consumer Profile. http://www.marsindonesia.com/products/business-reports/indonesianconsumerprofile-2015

Maruhum, T. (2001). Analisis perilaku konsumen terhadap atribut produk mi instan dan kaitan strategi pemasarannya. [Unpublished Masters thesis], Institut Pertanian Bogor. http://repository.sb.ipb.ac.id/407/

Mulyana, M., \& Syarif, R. (2007). Analisis Sikap dan Perilaku Konsumen Terhadap Pembelian Produk Studi Kasus Produk Susu Kental Manis Coklat Indomilk Pada Konsumen Jakarta, Jurnal IImiah Kesatuan. 9 (2).

Peter, J.P., \& J. C. Olson.(2010). Consumer Behavior and Marketing Strategy. 9th Edition. McGraw-Hill Irwin.

Primus, J., (2015). Mi Instan Punya Penggemar Paling Fanatik di Indonesia. Kompas.com.

https://money.kompas.com/read/2016/05/27/143128826/mi.instan.punya.pengge mar.paling.fanatik.di.indonesia.

R. D. Blackwell, Engel, F.J., dan P.W. Miniard. (2006). Consumer Behaviour (10th Edition). Thomson, Australia.

Rangkuti, F. (2015). Riset Pemasaran. Gramedia Pustaka Utama, Jakarta

Quester, P. G. (2013). Consumer Behaviour: Implications for Marketing Strategy. McGraw-Hill Education. Australia

Mohammad Wartaka and Sumardjono. Analysis of Consumer Behavior in Buying Instant Noodles (Case Studies In The Bogor City Area) 
The Management Journal of BINANIAGA Vol. 05, No. 02, December 2020

p-ISSN: 2527 - 4317, e-ISSN: $2580-149 x$

$6^{\text {th }}$ Accreditation Rating: April 04, 2019-April 03, 2024

Schiffman, L.G.\& Kanuk,L.L. (2015). Consumer Behavior (11th Edition). Prentice Hall, New Jersey.

Sumarwan, U. (2011). Perilaku Konsumen : Teori dan penerapannya dalam pemasaran, Ghalia Indonesia, Jakarta.

Sumarwan, U. (2013). Riset Pemasaran dan Konsumen, IPB Press, Bogor

Sutisna. (2001). Perilaku Konsumen dan Komunikasi Pemasaran. PT Remaja Rosdakarya

Tjiptono, F.(2002). Strategi Pemasaran. Penerbit Andi

Wartaka, M. (2016). Analysis of the Consumers Preferences of Lipstick Product and Its Relationship with the Segmentation of The Lipstick Products. The Management Journal of Binaniaga, 1(2), . doi : http://dx.doi.org/10.33062/mjb.v1i02.15

Word Instant Noodles Association. (2020). Global Demand for Instant Noodle. https://instantnoodles.org/en/noodles/market.html, accessed on 29/06/2020. 